\title{
ALTERNATIVE CORPORATE GOVERNANCE PARADIGM AND CORPORATE FINANCING: CAPITAL STRUCTURE DECISIONS IN EMPLOYEE-GOVERNED FIRMS
}

\author{
Matjaž ČRNIGOJ - Dušan MRAMOR \\ (Received: 19 November 2012; revision received: 27 June 2014; \\ accepted: 12 September 2014)
}

\begin{abstract}
Assuming an alternative corporate governance paradigm that puts employees in the firm's governance structures, as well as understanding their objective functions, we investigate capital structure decisions in employee-governed firms. Examining corporate capital structure decisions in 12 European countries, we provide strong empirical evidence of employees' conservatism in capital structure choice. We find that employee-governed firms operate with significantly lower leverage and that employee-governed firms are significantly less levered at the same amount of earnings volatility than firms governed by other stakeholders. We also find evidence that employee-governed firms, at least in some countries, rely on internal resources to a larger extent. However, we did not find evidence that employee-governed firms have to pledge more collateral to obtain debt financing. In addition to this, we find evidence that employee-governed firms choose debt of shorter maturity and, somewhat surprisingly, that employee-governed firms in some countries are faced with lower cost of debt compared to firms governed by other stakeholders and not higher cost of debt as expected because of credit rationing and limited borrowing capacity.
\end{abstract}

Keywords: corporate governance, employee-governed firm, capital structure, leverage, debt maturity, cost of debt

JEL classification indices: G32

Matjaž Črnigoj, corresponding author. Research fellow at the Institute for Economic Research, Ljubljana and Assistant Professor at the Faculty of Economics, University of Ljubljana, Slovenia. E-mail: crnigojm@ier.si

Dušan Mramor, Full Professor of Finance at the Faculty of Economics, University of Ljubljana, Slovenia. E-mail: dusan.mramor@ef.uni-lj.si 


\section{INTRODUCTION}

The modern capital structure theory that was developed in the last 50 years offers various avenues to explain corporate capital structure choice. In their seminal paper, Modigliani - Miller (1958) identified taxes as the main driver for the use of debt financing. The following research tried to answer why the interest tax shield provided by debt does not lead firms to borrow as much as possible. Modigliani - Miller (1963) then suggested that firms maintain reserve borrowing capacity and that the incremental tax advantage of debt declines as more debt is issued and the interest tax shield becomes less certain. Miller (1977) argues that the gain from leverage falls significantly if personal taxes are taken into account. DeAngelo - Masulis (1980) consider tax shields other than interest payments such as depreciation, depletion allowances, and investment tax credits. Others acknowledge bankruptcy costs and argue that optimal capital structure is defined by the trade-off between the value created by the interest tax shield and the value lost from bankruptcy costs. More recent literature focuses on agency costs and asymmetric information. Assuming that managers do not always act in the best interest of shareholders, the agency cost theory emphasises the role of debt as a disciplining device. By increasing the debt, shareholders reduce the free cash flow problem (Jensen 1986), but on the other hand, this causes the asset substitution problem (Jensen - Meckling 1976) and suboptimal investment (Myers 1977). Models based on asymmetric information hypothesise that capital structure choice can change the market's perception and affect the firm's value. Myers (1984) argues that the firm's financing process follows a pecking order, forcing the firm to exhaust internal resources first and when external resources are required, to first issue debt, while issuing equity capital only as a last resort. However, empirical evidence suggests that modern capital structure theory cannot sufficiently explain firms' capital structure decisions. Empirical evidence shows that firms' leverage is well beyond the levels suggested by the trade-off theory and that firms forgo significant tax benefits, and what is more, little of the variation in leverage is captured by other proposed determinates. Firms pursue very conservative financial policies and their debt ratios exhibit significant stability over time (Lemmon - Zender 2001). Moreover, the majority of variation is driven by unobserved firm specific time-invariant effect (Lemmon et al. 2008).

We argue that modern capital structure theory is unable to sufficiently explain firms' capital structure choice because it is developed on the assumption that firms are governed by shareholders and follow the goal of maximising shareholders' wealth. Assuming that firms are governed by shareholders could be an appropriate assumption for some of the firms, but the concept of value maximisation 
definitely does not encompass all the corporate governance arrangements and the resulting goals of the firms. Just a glance at the corporate governance systems around the world suggests that there are stakeholders other than shareholders that significantly affect firms' behaviour. In Germany, for example, the legal system is quite explicit that firms do not have the sole duty of pursuing the shareholders' interests. A system of codetermination enables employees' active participation in the firm's decision-making process. Specific corporate governance arrangements can be found in other European countries, Japan, etc. Besides, the new theory of the firm identifies alternative sources of power within the firm. According to the property rights theory that provides the foundation of the modern capital structure theory, power stems from ownership of physical assets. Hence, the firm is nothing but a collection of physical assets. It is no surprise, then, that there is no room for stakeholders other than shareholders, i.e. the owners of the assets. In contrast, Rajan - Zingales (1998) argue that power stems from control over a critical resource and that the main mechanism to allocate power is access; that is, the ability to use or work with this critical resource. An agent that is given privileged access to the resource receives no residual rights of control, but the opportunity to specialise his human capital to the resource and make himself valuable. Highlighting alternative sources of power, the new theory of the firm defines the firm in terms of unique assets, as well as in terms of people that have access to the critical resources. Thus, it brings stakeholders other than shareholders within the boundaries of the firm.

In this paper, we investigate corporate capital structure decisions, assuming an alternative corporate governance paradigm. We investigate capital structure decisions in an employee-governed firm. An employee-governed firm is a firm having employees in control or a firm that recognises employees' interests. In employee-governed firms, employees either actively participate in the firm's decision-making process or the stakeholders in control consider employees' interests in the firm's decision-making process. Having employees in control or recognising their interest implies that a firm would not follow the goal of maximising the value of the firm. One would intuitively expect that employees are maximising wages and other benefits. Theoretically, we can derive employees' objective function by paralleling their claim to the debtholders' claim in the firm. Merton (1974) showed that the value of debt is equal to the difference between the value of the firm's debt discounted at a risk-free rate and the value of the put option on the firm's assets or to the payoff to debtholders when the firm is solvent and the debt repaid, and the expected recovery given bankruptcy, weighted by the probabilities of bankruptcy. Applying this logic to the employees' claim, we find that the value of the employees' claim is equal to the difference between the value of the wages the firm owes to employees discounted at the risk-free rate and the 
value of the put option on the firm's assets or to the payoff to employees when the firm is solvent and the expected recovery in bankruptcy weighted by the probabilities of bankruptcy. Thus, employees' aim is to maximise the value of their wages and to minimise the value of the put option on the firm's assets. The put option value decreases with the value of the firm's assets, and it increases with the volatility of the firm's operating cash flow. However, as argued by Faleye et al. (2006), given that employees' careers with the firm are finite, it is assumed that they have limited horizons and that they employ an infinite discount rate in the period beyond their careers. Under this assumption, the employees' objective is to minimise the value of the put option. Employees are thus concerned with maximising wages, as well as being highly risk averse in their decisions in order to minimise the probability of bankruptcy.

Because an employee-governed firm maximises the wages and minimises the probability of bankruptcy, and it is not driven by shareholders' aspirations of value maximisation, we hypothesise that the capital structure choice of an employee-governed firm is very conservative. An employee-governed firm is expected to operate with lower leverage compared to the firm that is governed by shareholders. Lower leverage results from lower demand for debt because interest payments reduce cash flow, and thus wages, and because leverage increases bankruptcy risk. Besides, employee-governed firms are faced with a lower supply of debt due to credit rationing and the firm's limited borrowing capacity. It is expected that it would opt for a debt of shorter maturity and would be faced with a higher cost of debt. Shorter debt maturity is expected because employeegoverned firms mitigate the problem of adverse selection and the resulting credit rationing by signalling its quality to uninformed lenders by borrowing short term instead of long term (Flannery 1986; Diamond 1991). Higher cost of debt in employee-governed firms is expected because financial markets disfavour democratic firms (Gintis 1989).

The paper is structured as follows. In the second section we hypothesise about capital structure decisions in an employee-governed firm, we discuss the demand and supply of debt, as well as the choice of debt maturity and the cost of debt faced by an employee-governed firm. In the third section, we present the data and in the fourth, the methodology used in the empirical study. In the fifth section, we present the results. The sixth section concludes. 


\section{CAPITAL STRUCTURE DECISIONS IN EMPLOYEE-GOVERNED FIRMS}

\subsection{Demand for debt}

Intuitively, one would expect that an employee-governed firm that is maximising wages and minimising the probability of bankruptcy opts for the lowest possible level of debt because interest payments reduce cash flow, and thus wages, and because leverage increases bankruptcy risk. Lower demand for debt is not expected only in firms that are governed by employees, but also in firms that are governed by other stakeholders but are recognising employees' interests. Chang (1992) derived the firm's optimal debt level in a shareholder-governed firm accounting for nonmonetary restructuring related costs borne by employees. He identified optimal capital structure by investigating firms' restructuring decisions and deriving an optimal contract between shareholders and employees, which includes capital structure choice. Because employees have no incentive to restructure, debt is used to implement the first-best restructuring rule. If the expected output exceeds the debt payment, debt can be rolled over and restructuring will not occur; otherwise, the firm is forced to restructure because of the potential loss of control. He showed that an ex ante optimal level of debt that balances financial as well as nonfinancial benefits of restructuring is generally below the level that maximises the value of the firm if the restructuring-related costs to employees are accounted for.

In a similar manner, capital structure implications were investigated by Berk et al. (2007), who examined capital structure choice as part of an optimal employment contract. Their optimal employment contract guarantees employees job security, unless the firm is in financial distress, and pays a fixed wage that rises when employees are more productive than expected. This is why employees become entrenched. However, if the firm cannot make the interest payments at the contracted wage level, employees experience a temporary pay cut. If the firm's performance improves, wages return to the contracted level, and if it worsens further, the firm is forced into bankruptcy. Because entrenched employees are being paid more than the value they create, shareholders benefit from filing bankruptcy and normally have no incentive to avoid bankruptcy. Employees are terminated or replaced with more productive ones. As a result, entrenched employees face substantial bankruptcy costs such as taking a wage cut and earning the current market wage. The implications for optimal leverage occur ex ante because the amount of risk sharing between shareholders and employees depends on the leverage of the firm. Higher leverage implies a higher probability of bankruptcy and thus lower risk sharing. An optimal capital structure thus trades the benefits of risk sharing against the benefits of debt, such as tax shields, for example. Berk et al. (2007) argue that firms issue only modest levels of debt, and will also maintain cash 
balances despite these being associated with tax disadvantages. A firm's capital structure decisions are thus affected by the firm's idiosyncratic characteristics. Namely, firms with more risk-averse employees will operate with lower leverage. Because such firms attract other more risk-averse employees, they argue that the effect is self-enforcing. Heterogeneity in risk aversion in the labour market thus results in a clientele effect, implying a persistent heterogeneity in capital structure choices among otherwise identical firms.

The effects of human costs associated with bankruptcy in capital structure decisions have also been empirically examined. Chemmanur et al. (2009) tested whether firms with higher leverage pay their employees more and whether the resulting additional costs are large enough to offset the incremental tax benefits of debt. They found that leverage has a positive impact on average employee pay and that the additional total labour expenses associated with an increase in leverage are large enough to offset all the incremental tax benefits. The evidence thus suggests that the incremental labour costs associated with an increase in leverage are substantial enough to limit the use of debt. They also found that leverage positively affects the magnitude of CEO compensation. Finally, they tested the importance of employees' entrenchment. Examining old $v s$. new economy firms, associated with more and less entrenched employees and managers, they documented significant differences in the effect of leverage on average employee pay and CEO compensation. They found a positive impact of leverage on average employee pay only in old economy firms. Similarly, the impact of leverage on CEO compensation proves to be significant only in old firms, whereas leverage in new economy firms tends to affect only the cash pay of the CEO.

\subsection{Supply of debt}

Credit market equilibrium is characterised by credit rationing. Following the impetus of Jaffe - Russell (1976), Keeton (1979) and Stiglitz - Weiss (1981, 1983), economists have come to the conclusion that credit rationing is driven by the asymmetry of information between borrowers and lenders, adverse selection, and the moral hazard problem. Lenders and borrowers have asymmetric information about the quality of the borrowers. When lenders cannot separate good borrowers from bad borrowers, bad borrowers are more likely to be selected than good borrowers. A higher interest rate tends to attract bad borrowers because good borrowers are willing to pay only a low interest rate and are thus driven out of the market. Lenders therefore want to keep interest rates low in order to attract good borrowers. As a result, some of the borrowers that want credit cannot obtain it. Moral hazard problem refers to the problem of inducing the borrower to behave 
as desired by the lender when the borrower's actions cannot be observed and contracted for. Because of the interest rate's incentive effects, the behaviour of the borrower is likely to change with the increase in the interest rate. A higher interest rate decreases the borrower's return on projects that succeed and thus induces them to undertake riskier projects. For this reason, lenders again want to keep interest rates low in order to attract good borrowers and, as a result, some borrowers are unable to obtain credit, whereas the borrowers that do obtain credit may be faced with limited borrowing capacity.

Firms mitigate the adverse selection problem and credit rationing by signalling the true quality to uninformed lenders; they invest their own funds in projects (Leland - Pyle 1977), pledge collateral (Chan - Kanatas 1985; Bester 1985, 1987; Besanko - Thakor 1987), borrow rather short-term than long-term and secure fewer resources than needed in the future and thus convey to uninformed lenders the confidence about their prospects and that they are not afraid of refinancing short-term debt (Flannery 1986; Diamond 1991), and choose an appropriate payout policy (Miller - Modigliani 1961; Bhattacharya 1979; Miller - Rock 1985; John - Williams 1985; Bernheim - Wantz 1985). Firms mitigate the moral hazard problem and increase their borrowing capacity by pledging real assets as collateral (Bester 1987), by building reputation capital, and by diversification (Diamond 1989), as well as by bringing down the bargaining power of human capital (Hart - Moore 1994).

We expect that the problem of credit rationing and limited borrowing capacity is more severe in an employee-governed firm compared to the problem in a firm that is governed by shareholders. Employees have limited personal wealth and are more risk averse compared to shareholders, and they also disfavour large payouts, that is why an employee-governed firm is deprived of using the signalling mechanisms to convey its quality to uninformed lenders, and to mitigate lenders' informational disadvantage and the adverse selection problem. Limited personal wealth and risk aversion as well as the bargaining power of human capital make it difficult to control the moral hazard problem. This results in lower supply of debt to employee-governed firms. Being left with the only possibility to signal the quality to uninformed lenders by borrowing short term and pledging collateral, we expect an employee-governed firm to opt for a debt of shorter maturity as well as to be forced to pledge more collateral to obtain debt financing. In addition, it is believed that financial markets disfavour democratic firms (Gintis 1989). That is why it is expected that an employee-governed firm, besides being faced with a lower supply of debt, will be faced also with a higher cost of debt compared to a firm that is governed by shareholders. Rather than lending to employeegoverned firms, lenders prefer to lend to firms governed by shareholders, which better protect their investments by enforcing value-maximising decisions. 


\section{DATA}

\subsection{Database and samples}

We empirically examined capital structure decisions in large firms from 12 European countries: four Western European countries (France, Germany, Sweden, and the United Kingdom), five Central and Eastern European countries (the Czech Republic, Hungary, Poland, Slovakia, and Slovenia) and the three Baltic states (Estonia, Latvia, and Lithuania). ${ }^{1}$ The choice of the countries is intended to cover the various legal environments in Europe. La Porta et al. $(1997,1998)$ argue that differences in the development of the financial system and thus the use of external resources stem from the differences in investor protection. They provide evidence that legal rules and the quality of law enforcement on investor protection vary systematically by legal origin. Legal origin can be English, French, German, or Scandinavian. English law is common law, whereas French, German, and Scandinavian laws are part of the civil law tradition. Common law protects investors more than civil law. Within the civil law tradition, investors are better protected by German and Scandinavian law than by French law. Central and Eastern European countries' and the Baltic states' (CEB) current legal systems are based on German civil law. Despite scoring higher than the other civil law families on legal rules, they are relatively less protective in terms of law enforcement (Pistor et al. 2000).

The data are from the AMADEUS database of Bureau van Dijk. ${ }^{2}$ Although data were collected for an eleven-year period, the panels cover only a sevenyear period, i.e., the period from 2001 to 2007 . This is due to the fact that for some explanatory variables, data from the four preceding years are required. The panels consist of a relatively large number of observations; however, when the variables of interest are calculated, it drops significantly. For the corresponding period there are 19,088 observations available in France, 5,626 observations in Germany, 4,559 observations in Sweden, 7,521 observations in the UK and 9,551 observations in CEB. ${ }^{3}$ Due to the poor quality of the data, unbalanced panels are considered. For example, in Sweden, which has the highest percentage of firms

1 We restrict the analysis to firms with more than 250 employees and as it is typical for capital structure research, we exclude financial firms.

2 AMADEUS is a comprehensive pan-European database containing financial information on over 10 million public and private companies in 38 European countries. It includes data about 24 balance sheet items and 25 profit and loss account items as well as some general descriptive information such as the firm's legal form, year of incorporation, industry code, and number of employees. Moreover, unlike other pan-European sources, it includes ownership information. In addition, outliers are excluded. We excluded the lowest and the highest percentile of observations according to the variables used in our regression models. 
represented in every year of the period under investigation, less than half of the firms could be used if balanced panels are used. The percentage amounts to less than 30 percent in other countries.

\subsection{Descriptive statistics}

Table 1 shows that in our sample the average firm in France, Sweden, and the UK is roughly of the same size, while we observe a larger average firm size in Germany and a smaller average firm size in CEB. The average firm in France, Sweden, and the UK generated between 200 and 300 million EUR of sales, while the average German firm slightly more than 500 million EUR, whereas the average CEB firm less than 100 million EUR of sales. The average firm in France, Sweden, and the UK employed around 1,500 employees, while the average German firm employed more than 2,000 employees and the average CEB firm less than 1,000 employees. In all countries, the median value of sales, total assets, and number of employees is well below the mean value, suggesting that most of the firms are smaller than the mean firm.

The existing literature on cross-country capital structure research shows that firms' leverage differs on average across countries. As found by Rajan - Zingales (1995), the average firm in Germany has lower total debt ratio than the average firm in France, but in contrast to their findings, relatively higher leverage is observed in the UK firms. The mean (median) value of total debt ratio amounts to 48.7 percent (46.6 percent) in Germany, 54.9 percent ( 54.8 percent) in France, and 61.3 percent (62.2 percent) in the UK. Similar leverage to the leverage in Germany is observed in Sweden, 45 percent (40.9 percent). CEB firms operate on average with relatively high leverage 58.3 percent ( 60.6 percent). On the other hand, analysing long-term debt ratio, we surprisingly observe the highest leverage in CEB, followed by firms in the UK, Germany, and Sweden. In all countries, the median long-term debt is well below the mean value. Surprisingly, low longterm debt ratio is observed in France.

The next thing that has an important implication for our study concerns the evolution of leverage. Despite the fact that average leverage is fairly similar across years, there are significant differences among groups of firms that pursue different financing policies. We constructed three groups of firms based on their total debt ratio in 1998, defined as firms with low, medium and high total debt ratio, and computed the average total debt ratio in all subsequent 9 years, holding the composition of the groups constant. ${ }^{4}$ The groups were defined using $25^{\text {th }}$ and $75^{\text {th }}$

4 For Germany, we constructed the groups in 2001 and analyse the evolution of leverage in the subsequent 6 years because of the low number of firms available in the period 1998-2000. 


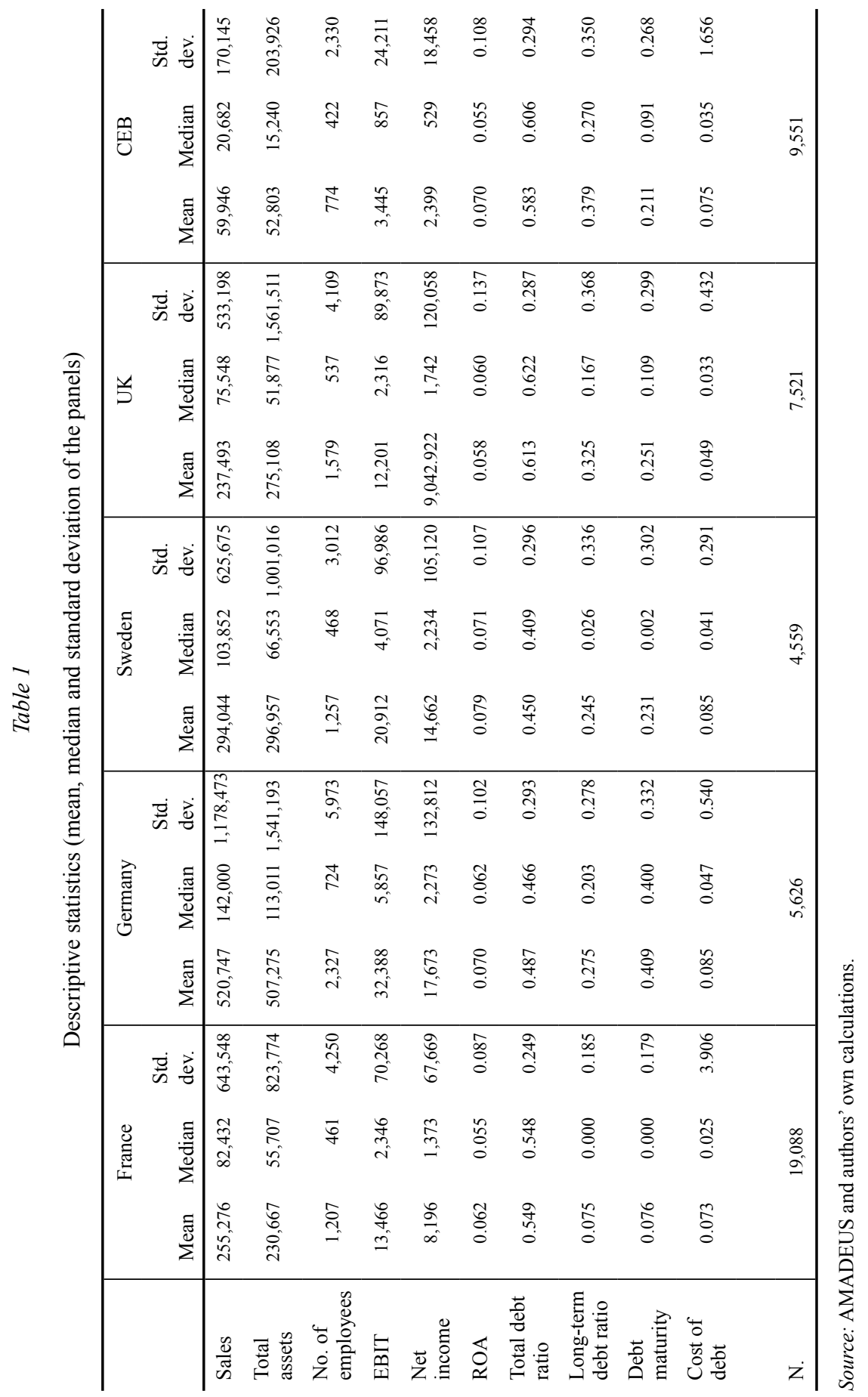


percentiles as boundaries between the groups. The results can be seen in Figure 1. Consistent with the findings of Lemmon et al. (2008), we observe significant differences in leverage between the groups. Although one can observe some convergence among the leverage of the groups over time, the difference among the groups remains highly statistically significant.
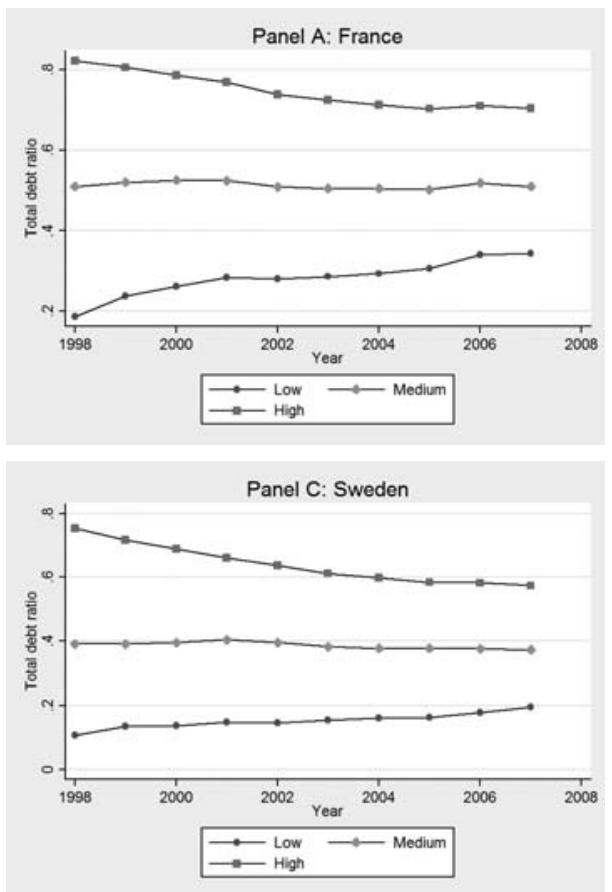
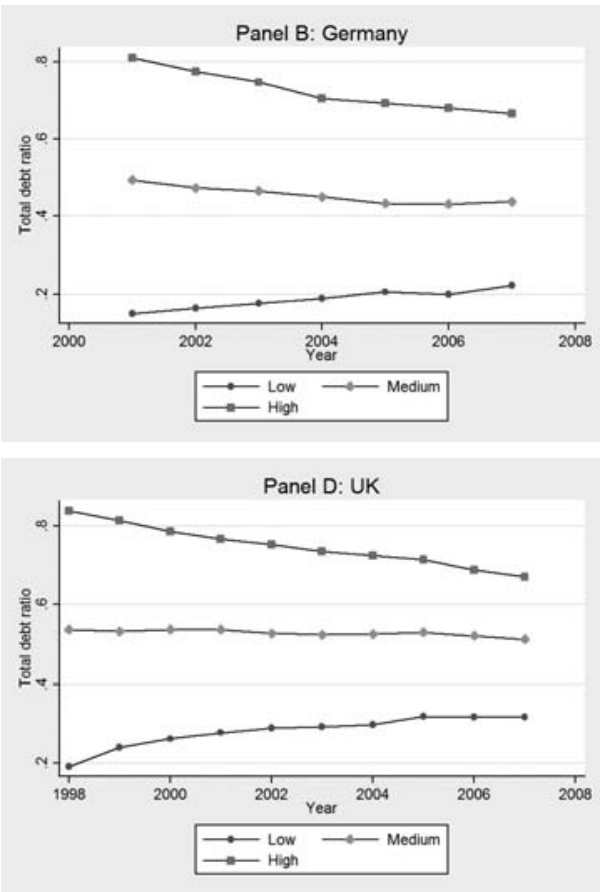

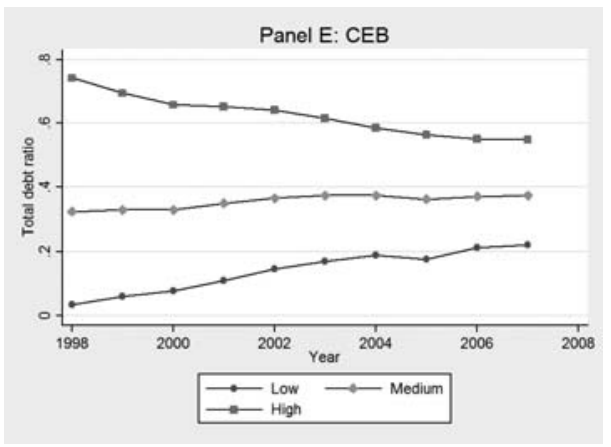

Figure 1. Evolution of leverage

Notes: The panels show evolution of leverage in 10-year period of three groups of firms based on their total debt ratio in year 1998 (firms with low, medium and high total debt ratio). The evolution of leverage in Germany is shown only in a 6-year period due to the small number of firms available in the whole studied period.

Source: AMADEUS and authors' own calculations. 
As already pointed out by Lemmon et al. (2008), the differences in the leverage of different groups of firms may be simply capturing cross-sectional variation in the underlying capital structure determinants identified by modern capital structure theory, such as profitability, tax status, bankruptcy cost, agency cost, and asymmetric information. For example, if profitability tends to be negatively correlated to leverage, firms included in the group with low leverage may simply be more profitable firms. We address this issue and based on the results it is not possible to conclude that the differences in leverage correspond to cross-sectional variation in profitability, tangibility of assets, or firm size.

Based on the results obtained here, it can be argued that capital structure decisions are driven by a factor with a significant permanent component. Because capital structure decisions are significantly affected by corporate governance issues, such as who governs the firm and what the objective function of the stakeholder in control is, we argue that this is one possible direction to look for a firmspecific time-invariant component.

\section{METHODOLOGY}

\subsection{Leverage measures and explanatory variables}

A firm's leverage ( $L E V)$ is measured using two different ratios: long-term debt ratio, which is defined as the ratio of long-term debt to the value of total capital, i.e. equity capital and long-term debt, and total debt ratio that takes into account long-term debt and short-term debt. Even though only long-term debt represents long-term financing resources that are considered in capital structure decisions and we are interested primarily in the use of long-term debt, we have to rely on total debt in some countries because the data about the long-term debt does not look reliable. ${ }^{5}$ Leverage is measured only in book values because the samples mostly consist of unlisted firms. Debt maturity (MAT) is approximated by the ratio of long-term debt to total debt, and cost of debt (COST) by the ratio of interests paid to total debt.

Employees' ability to affect capital structure decisions stems from at least three different sources. Employees can affect capital structure decisions if they have ownership rights in the firm. However, employees can govern the firm or affect a firm's decision-making process also without owning the firm. As already mentioned, in Germany, for example, a system of codetermination allows ac-

As seen in Table 1, we observe very low average ratio of long-term debt in France, very low median long-term debt ratio in Sweden, and relatively high long-term debt ratio in CEB. 
tive participation of employees in the firm's decision-making process through workers' councils and employee and union representation on supervisory boards. Therefore, the more the corporate governance system recognises employees' interest, the more employees' participation in decision-making is expected. Finally, employees' ability to affect capital structure decisions depends on the ownership structure and the effectiveness of monitoring by the shareholders.

Employees' ownership rights cannot be uniquely determined within the AMADEUS because it does not distinguish employee-owned and managerowned firms, and reports them together. That is why we did not include employees' ownership rights in our models. We could have tried analysing the effect together with manager-owned firms, however, because of conflicting hypotheses about the effect of employees' ownership and managers' ownership on leverage, it would not be possible to isolate the effect of employees' ownership. As argued by Jensen - Meckling (1976), the higher the managerial ownership, the more powerful the incentives to make value-maximising decisions and the higher the leverage of the firm. Focusing on managerial control motivations, Haris - Raviv (1988) and Stulz (1988) argue that managers use debt to increase their voting power, whereas Israel (1991) argues that this is to affect the distribution of cash flows between voting and nonvoting shares in order to influence the outcome of the takeover contest. On the other hand, as argued by Faleye et al. (2006), firms in which labour has ownership stakes choose more conservative capital structures than value maximising firms that are owned by shareholders.

The extent to which employees' interests are recognised and their ability to participate in decision-making result from employees' entrenchment. Employees' entrenchment allows employees to extract rents through wages and other benefits. Following Črnigoj - Mramor (2009), employees' entrenchment and rent extraction are measured by their ability to increase wages relatively to the increase of value added. In particular, it is approximated by the difference between the growth rate of labour costs per employee and the growth rate of value added per employee (DIFF). Because employees' entrenchment and their ability to affect decision-making within the firm are rather constant or could change only over a longer period of time, we calculated the growth rates over the whole period for which we have data available, i.e. as the growth rate between the first and the last year the firm has corresponding data available. The higher the difference, the more entrenched the employees, the lower the leverage. As argued by Flannery (1986) and Diamond (1991), by borrowing short-term instead of long-term and by securing fewer resources than needed in the future, firms signal their creditworthiness. An employee-governed firm which is deprived of using signals, such as investing their own funds in the firm, pledging collateral, and payout policy, can only signal its creditworthiness by borrowing short-term. It is thus expected 
that an employee-governed firm opts for debt of shorter maturity compared to firms governed by shareholders. Because financial markets tend to disfavour democratic firms (Gintis 1989), it is also expected that employee-governed firms will be faced with a higher cost of debt.

Finally, employees' impact on leverage decisions depends on the ownership structure and the effectiveness of monitoring by the shareholders. It is expected that the higher the ownership concentration, the higher the incentives to monitor and the enforcement of value-maximising decisions by the shareholders. As argued by Jensen (1986), debt is one of the disciplining mechanisms. Thus, the higher the ownership concentration, the higher the leverage. Ownership concentration should also result in longer debt maturity and lower cost of debt. Ownership concentration and the effectiveness of monitoring is approximated by the ownership share of the largest shareholder (OWNCON).

Modern capital structure theory, that was primarily derived for firms in the developed economies, but, as argued by Hernádi - Ormos (2012a, b), can also be used to explain financial decisions in Central and Eastern European countries, suggests that a firm's leverage is driven by factors such as profitability, tangibility of assets, firm size, and so on. That is why a set of control variables is used. Trying to take into account the factors that exert the most significant effect on capital structure decisions as well as the limitation of data availability in the AMADEUS database, five factors are considered. These are profitability, tangibility of assets, earnings volatility, firm size, and firm growth.

In the literature, positive as well as negative effect of profitability can be found. According to the pecking order hypothesis (Myers 1984), leverage tends to be negatively correlated to profitability. Profitability can also proxy for growth opportunities and again have a negative impact on leverage. Myers (1977) viewed part of the corporate assets, particularly growth opportunities such as call options, whose value depends on discretionary future investments, and showed that by issuing risky debt, a firm reduces its value by inducing a suboptimal investment strategy or by forcing the firm and its debt holders to bear the costs of avoiding the suboptimal strategy. In contrast, the trade-off theory suggests that profitability is positively associated with leverage. More profitable firms have a larger income to shield and operate with higher leverage compared to less profitable firms (Modigliani - Miller 1958, 1963).

Tangibility of assets is expected to have a positive impact on leverage. By pledging tangible assets as collateral, firms decrease the bankruptcy cost. Myers - Majluf (1984) also suggest that firms may find it advantageous to sell secured debt because firms securing debt by collateral with known values avoid the costs associated with underpricing resulting from asymmetric information. Jensen Meckling (1976) argue that if debt is collateralised, the borrower is restricted 
to using the funds for the specified project, whereas Myers (1977) expects that funds are used to pursue a more optimal investment policy. This means a lower free cash flow and lower debt overhang problem.

Firms with more volatile earnings are expected to operate with lower leverage. Firms with more volatile earnings have a higher bankruptcy cost and thus according to the trade-off theory, a lower optimal capital structure.

The effect of firm size is again ambiguous. Warner (1977) found that direct bankruptcy costs appear to constitute a larger proportion of firm value as the firm size decreases. Opler - Titman (1994) also stressed the importance of the indirect costs of bankruptcy. They found that highly levered firms lose a substantial market share to their less levered competitors, as well as market value of equity, in downturns. Larger firms tend to be also more diversified and thus less prone to go bankrupt (Titman - Wessels 1988). However, size can also proxy for information asymmetry and thus difficulties in tapping the equity market. Therefore, following Scott (1977), who showed that small firms tend to be faced with a higher cost of issuing equity compared to larger firms, it is expected that small firms will operate with higher leverage.

Faster-growing firms, on the one hand, need more resources and taking into account pecking order considerations to accumulate higher debt levels. However, on the other hand, firm growth can also proxy for growth opportunities that result in higher information asymmetry. Then a negative impact is expected. As suggested by Jensen - Meckling (1976) and Myers (1977), shareholders tend to expropriate wealth from bondholders by investing in suboptimal fashion. Therefore, higher agency costs, which are also associated with growth opportunities, again mean lower leverage.

Profitability $(R O A)$ is approximated by the return on assets, calculated as the ratio of the firm's earnings before interests and taxes to the average value of total assets. Asset tangibility (TANG) is approximated by the ratio of the value of fixed assets to the value of total assets. Earnings volatility (SDROA) is approximated by the standard deviation of ROA, calculated from a three-year period. Firm size (SIZE) is approximated by the logarithm of sales. Firm growth $(G S)$ is approximated by the growth rate of sales.

Being aware of persistent differences in the firms' leverage across industries, industry-specific effects are taken into account. To cover the 15 industries defined by sections in NACE Rev 1.1. industries, 14 dummy variables are included (one industry is treated as a base category). 


\subsection{Regression models and estimation techniques}

We first analyse the differences in leverage in employee-governed firms and the firms governed by other stakeholders. We estimated the following regression model:

$$
L E V=\alpha+\beta_{1} D I F F_{i}+\beta_{2} O W N C O N_{i t}+\beta_{3, j} \operatorname{CONTROLS}_{i t}+\varepsilon_{i t}
$$

in which:

$L E V \ldots \ldots \ldots \ldots$. . . long-term/total debt ratio;

DIFF ............ employees' entrenchment; and

OWNCON ............ ownership concentration.

CONTROLS include:

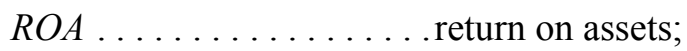

TANG .............. asset tangibility;

SDROA .......... earnings volatility;

SIZE ............ firm size;

$G S \ldots \ldots \ldots \ldots \ldots$ firm growth; and

industry dummies.

Because of the specific demand for debt of employee-governed firms and the supply of debt to these firms it is also expected that employee-governed firms rely on internal resources to a larger extent, have to pledge more collateral, and are less levered at the same amount of earnings volatility compared to the firms governed by other stakeholders. Therefore, a dummy variable, which takes a value of 1 if the firm is employee-governed and 0 otherwise $\left(D_{D I F F}\right)$, instead of DIFF, as well as the corresponding interactive terms are used to test for the different impacts through these capital structure determinants. ${ }^{6}$ To test for these differences, we estimated the following regression model:

$$
\begin{aligned}
L E V= & \alpha+\beta_{1} D_{D I F F i}+\beta_{2} O_{W N C O N_{i t}}+\beta_{3} D_{D I F F i} R O A_{i t}+\beta_{4} D_{D I F F i} T_{A N G} \\
& +\beta_{5} D_{D I F F i} S D R O A_{i t}+\beta_{6, j} C_{i t} O N T R O L S_{i t}+\varepsilon_{i t}
\end{aligned}
$$

6 The dummy variable indicating 'employee-governed' is defined using DIFF, the $75^{\text {th }}$ percentile being the boundary separating the value 1 from 0 . Interactive terms are defined by multiplying a $D_{D I F F}$ by $R O A, T A N G$, and $S D R O A$. 
To analyse the differences in debt maturity (MAT) in employee-governed firms and the firms governed by other stakeholders, we estimated the following regression model:

$$
M A T=\alpha+\beta_{1} D_{I F F_{i}}+\beta_{2} O_{W N C O N}+\beta_{3, j} \operatorname{CONTROLS}_{i t}+\varepsilon_{i t} .
$$

To see if employee-governed firms are faced with higher cost of debt (DEBT) compared to the firms governed by other stakeholders, we estimated the following regression model:

$$
\operatorname{COST}=\alpha+\beta_{1} \operatorname{DIFF}_{i}+\beta_{2} \mathrm{OWNCON}_{i t}+\beta_{3, j} \operatorname{CONTROLS}_{i t}+\varepsilon_{i t} .
$$

The debt maturity regression model includes the same explanatory variables as the leverage regression model, while the cost of debt regression model includes in addition the leverage of the firm.

The parameters of the regression models were first estimated as pooled regression using the OLS estimator, and then by the Hausman-Taylor estimator (HT) and the between-group estimator (BE). We cannot rely on the fixed-effect and random-effect estimates, as the former sweeps out time-invariant explanatory variables (employees' entrenchment), while the latter is rejected by the Hausman test. The HT estimator, on the one hand, overcomes the problem of the random effect estimator that requires unobserved individual effects to be uncorrelated with the explanatory variables, and on the other hand, it accommodates the possibility to include variables that are time-invariant. The BE estimator estimates the parameters of the model using group means variability. This again allows us to use variables that are time-invariant, though losing within-group variability.

\section{RESULTS}

\subsection{The firm's leverage}

The regression results support the hypothesis that employee-governed firms operate with lower leverage compared to the firms governed by other stakeholders. As seen in Table 2, the results show that a firm's leverage is negatively correlated to employees' entrenchment, approximated by their ability to extract rents, in particular by the difference between the growth rate of labour costs per employee and the growth rate of value added per employee (DIFF), in Germany, the UK, and CEB. The HT estimate of the coefficient amounts to -0.142 in Germany and even higher in the UK $(-0.302)$ and CEB $(-0.314$ if leverage is approximated by 


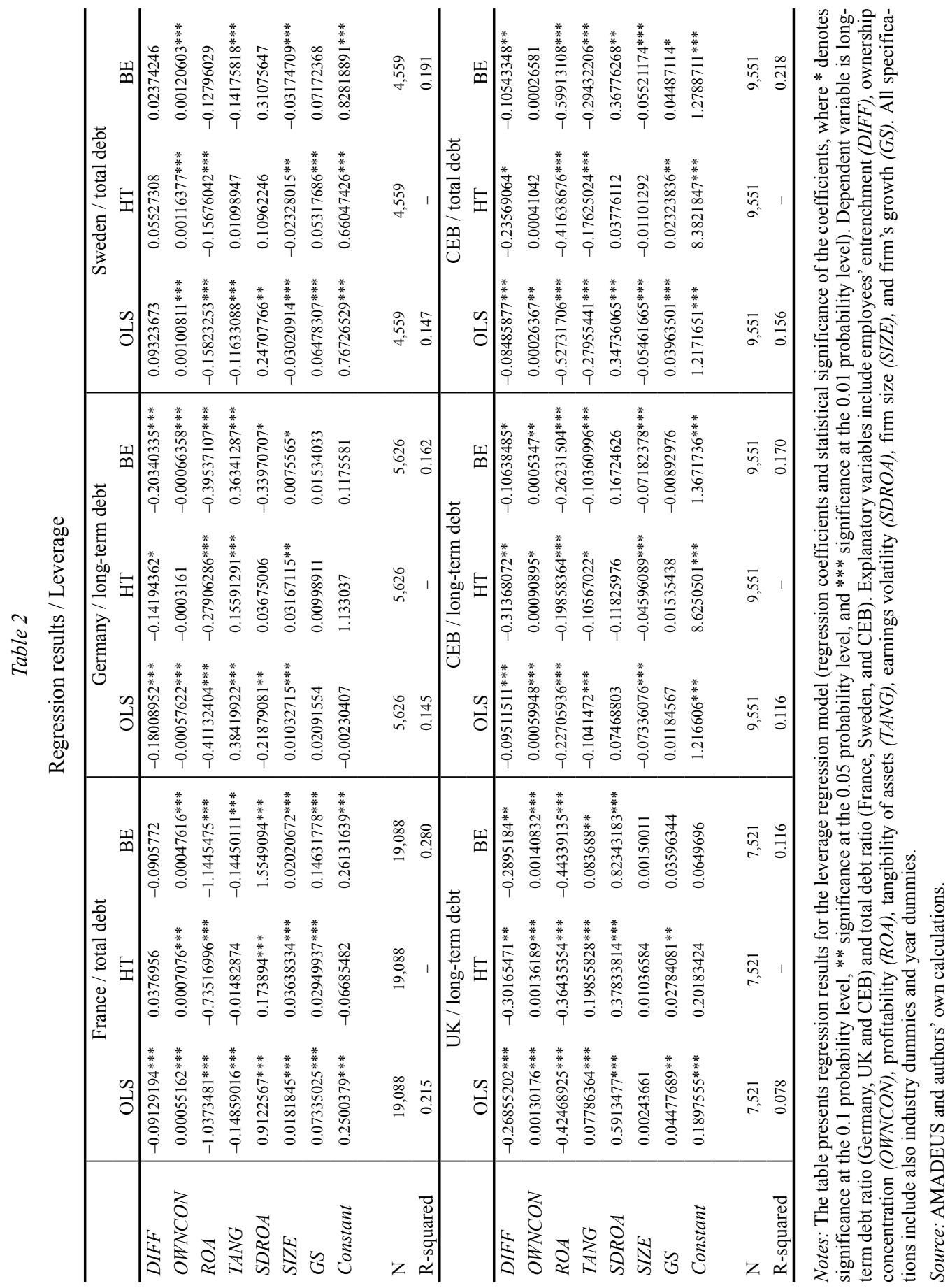


long-term debt ratio and -0.235 if leverage is approximated by total debt ratio). ${ }^{7}$ A weak evidence of negative effect is observed also in France, while the coefficient is not statistically significant in Sweden. Due to the doubts in the reliability of the data on long-term debt ratio in France and Sweden, we did not use longterm debt ratio as the dependent variable and we relied on total debt ratio in these countries. That is why the insignificant coefficient in France and Sweden, where total debt is used as the dependent variable, is not surprising, because we expect that employee-governed firms avoid using long-term debt, but not short-term debt. Employee-governed firms are deprived of using signals such as investing their own funds in the firm, pledging collateral, and payout policy, and can signal their creditworthiness only by borrowing short-term in order to mitigate the adverse selection and moral hazard problem, and the resulting credit rationing and limited borrowing capacity.

In line with the hypothesis that employee-governed firms operate with lower leverage, we observe also that ownership concentration and the effectiveness of monitoring, approximated by the ownership share of the largest shareholder $(O W N C O N)$, positively affect firm's leverage. This suggests that only large shareholders are powerful enough to force the firms to increase the use of debt and thus activate this disciplining mechanism to align the interests of the stakeholders in control with their own interests.

In addition, employees' conservatism in capital structure decisions is confirmed by observing that employee-governed firms are less levered at the same amount of earnings volatility than firms governed by other stakeholders; however, the coefficient is statistically significant only in some countries. We observe a statistically significant negative OLS and BE estimate of the interactive term $D_{D I F F} S D R O A$ in Germany and CEB, but not in the UK (Table 3). Besides, we observe weak evidence that employee-governed firms to a larger extent rely on internal resources. Statistically significant negative coefficients for the interactive term $D_{D I F F} R O A$ were found only in France and Sweden. On the other hand, it would be difficult to argue that employee-governed firms have to pledge more collateral when issuing debt than firms governed by other stakeholders.

Going back to Table 2 and analysing the effects of the most widely tested capital structure determinants, one can find that in line with the pecking order hypothesis, leverage is negatively correlated to profitability across all countries $(R O A)$. This is observed in all four Western European countries and eight European transition economies (CEB). Similar findings for CEB countries were obtained by

Being aware that short-term debt is often used as a long-term financing resource in CEB (because of being refinanced and rolled over at the maturity), we estimated the model in CEB using both measures for leverage: long-term debt ratio and total debt ratio. 


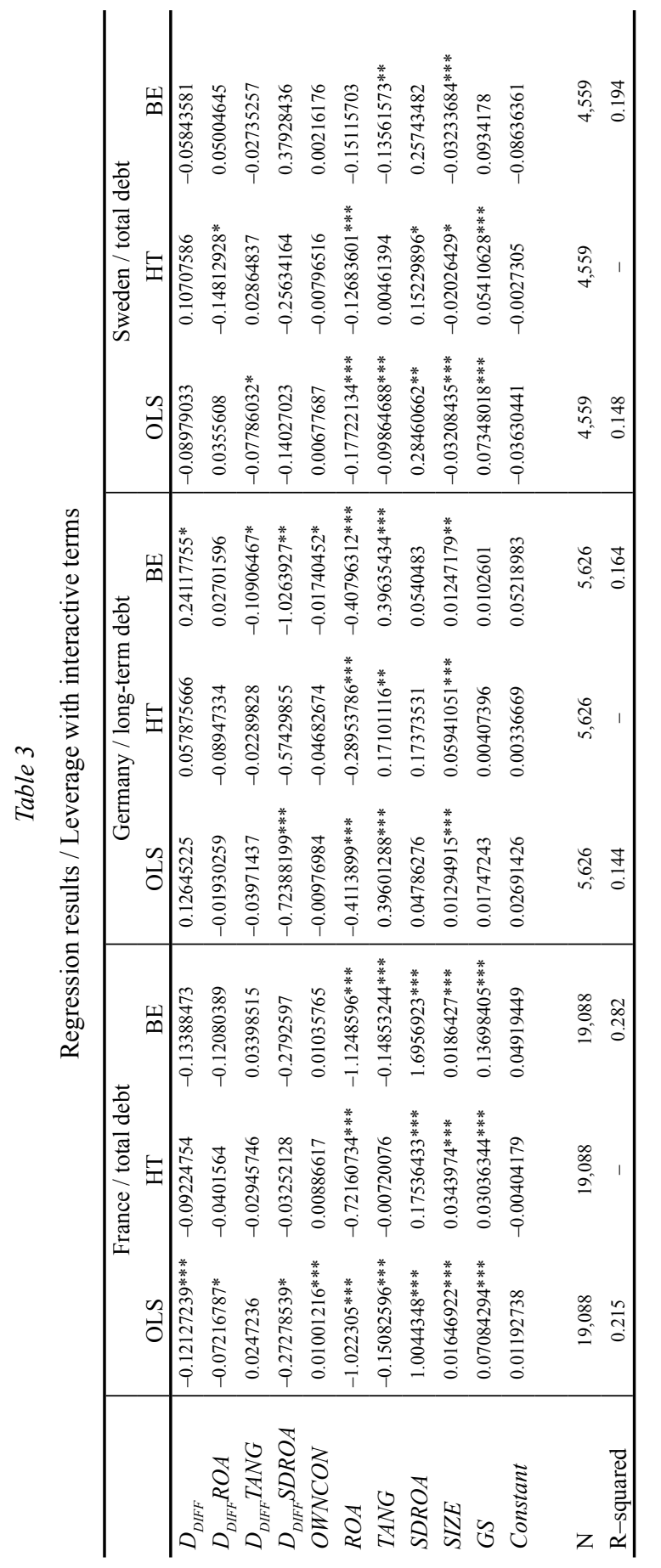




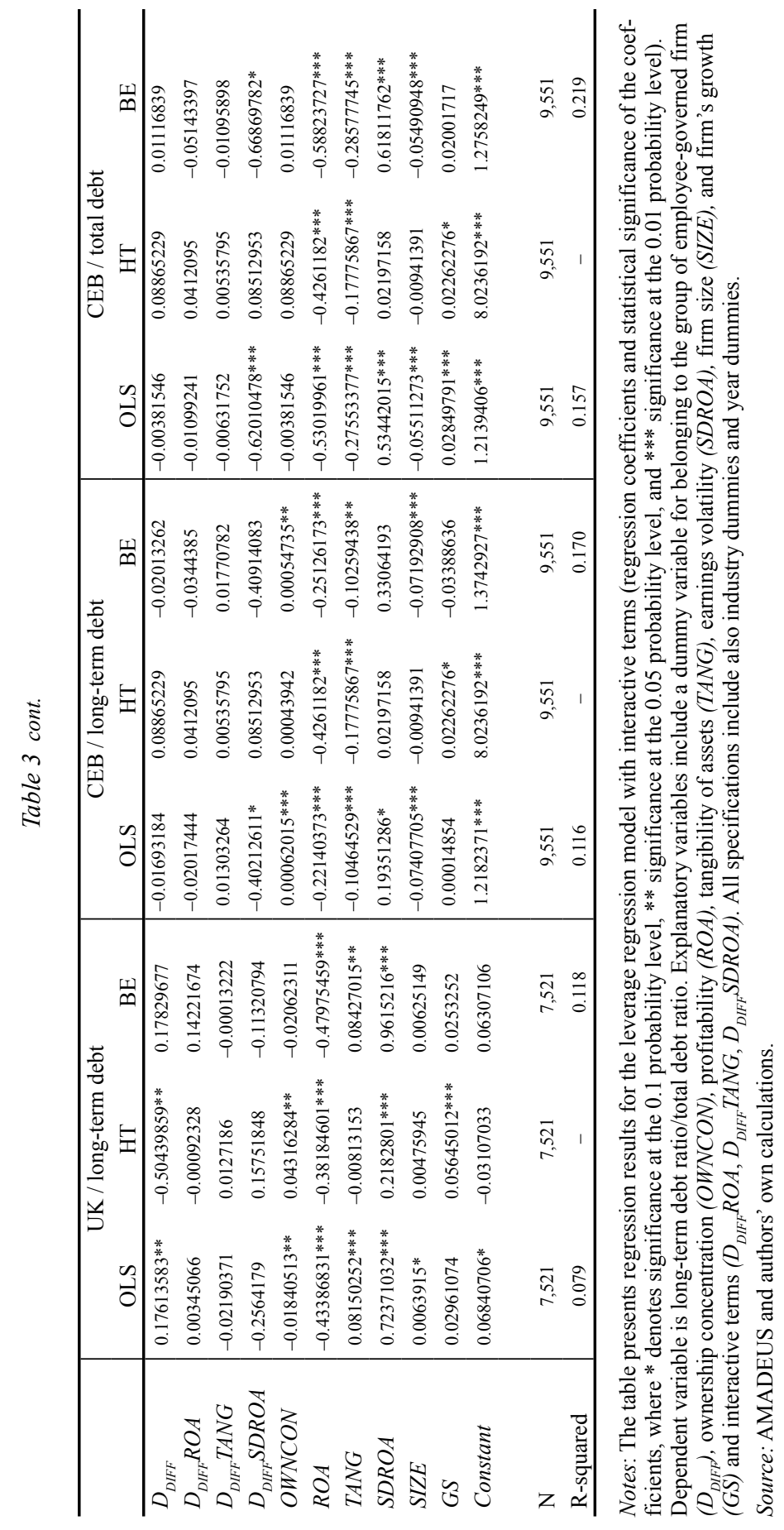


Hernádi - Ormos (2012a, b) for Central and Eastern European countries. This suggests that firms in these countries rely on internal resources and increase leverage only when internal resources are exhausted. However, profitability can also proxy for growth opportunities. Negative correlation then implies difficulties in borrowing against growth options.

As found by previous studies, long-term debt is positively correlated to tangibility of assets $(T A N G)$. When total debt is taken into account (France and Sweden), a negative correlation is observed. ${ }^{8}$ The findings imply that firms have to pledge collateral when raising long-term debt, whereas collateral requirements do not play an important factor when a firm is raising short-term debt.

In contrast to the expectations, leverage does not exhibit a negative correlation to earnings volatility (SDROA). This is found when total debt as well as longterm debt is taken into account. The result may be due to the possible non-monotonic relation between leverage and earnings volatility that according to Morellec (2004) prevails if a manager-shareholder conflict is assumed. He argued that, for lower volatility levels, the manager is completely entrenched and the only effect of increased volatility is an increase in bankruptcy costs. This results in a negative relation between volatility and leverage. For higher levels of volatility, an increase in volatility increases bankruptcy risk as well as the degree of managerial entrenchment. Something similar can be expected if another insiders-outsiders conflict is assumed.

Finally, we observe an ambiguous effect of firm size (SIZE), being positively correlated to leverage in some countries (France and Germany), and negatively correlated to leverage in other countries (Sweden and CEB). The results also provide a weak evidence of a positive correlation between leverage and firm growth (GS).

\subsection{Debt maturity}

As seen in Table 4, the results in general also confirm the hypothesis that employee-governed firms opt for debt of shorter maturity. By borrowing short-term, firms signal to uninformed lenders their quality and thus mitigate the adverse selection problem and the resulting credit rationing. Employee-governed firms resort to borrowing short-term because they are deprived of using other ways of signalling. Debt maturity is negatively correlated to employees' entrenchment (DIFF) in Germany and the UK, but not in CEB. However, in contrast to the

8 Testing the leverage regression model using total debt as the dependent variable for other countries reveals that tangibility of assets is positively correlated to total debt only in Germany. 


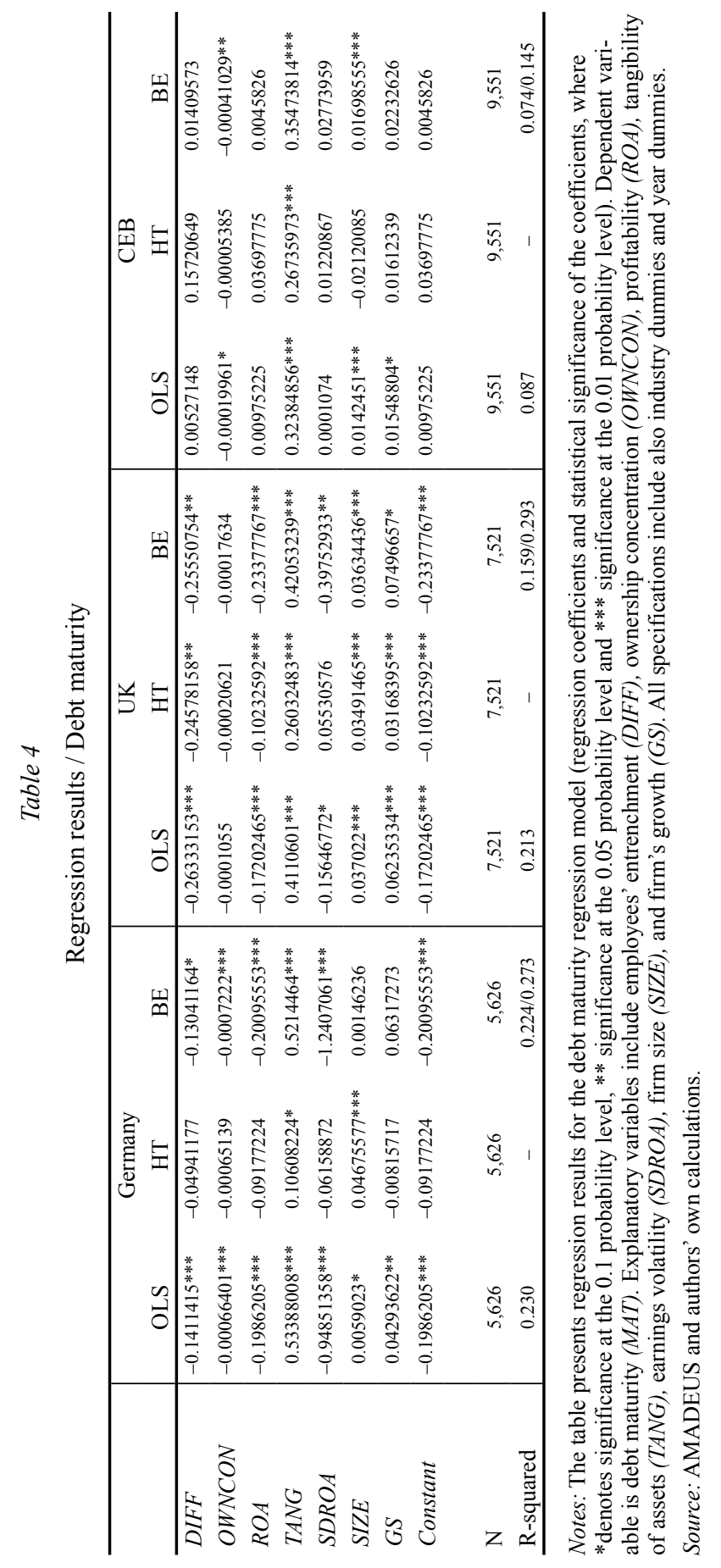


expectations, we observe a negative association between debt maturity and ownership concentration, and the effectiveness of monitoring $(O W N C O N)$. Based on the findings, it can be concluded that if shareholders use debt to control free cash flow problems, they more often use short-term than long-term debt.

Debt maturity is negatively correlated to profitability (ROA) and earnings volatility (SDROA), and positively correlated to tangibility of assets (TANG), firm size (SIZE), and firm growth (GS). The results confirm the findings obtained when testing the leverage regression model that firms have to pledge collateral when raising long-term debt.

\subsection{Cost of debt}

The evidence suggests that employee-governed firms are generally not faced with a higher cost of debt. ${ }^{9}$ Moreover, in contrast to the expectations, the evidence implies a negative impact of employees' entrenchment (DIFF) on the cost of debt in some countries. The effect is statistically significant in France, Sweden, and partly in the UK. Based on the results, it can be concluded that employee-governed firms in these countries are actually faced with lower cost of debt compared to the firms governed by other stakeholders. Again, mixed evidence is obtained for the impact of ownership concentration and the effectiveness of monitoring (OWNCON).

\section{CONCLUSIONS}

Assuming an alternative corporate governance paradigm that puts employees in the firm's governance structures as well as understanding their objective functions, we investigate capital structure decisions in employee-governed firms. We took into account various factors that determine the ability of employees to affect firm's decision-making process such as employees' ownership rights, employees' entrenchment, and the firm's ownership concentration. We provide strong empirical evidence of employees' conservatism in capital structure decisions. The results show that employee-governed firms operate with lower leverage compared to the firms governed by other stakeholders, and that employee-governed firms are less levered at the same amount of earnings volatility than firms governed by other stakeholders. In addition, we also found weak evidence that employeegoverned firms rely on internal resources to a larger extent. However, the results

9 Results are not reported in the paper, but are available from the authors upon request. 
do not support the hypothesis that employee-governed firms have to pledge more collateral to obtain debt financing compared to the firms governed by other stakeholders. Besides, we found evidence that employee-governed firms choose debt of shorter maturity. Not least, somewhat surprisingly, we found that employeegoverned firms in some countries are faced with lower (and not higher) cost of debt compared to the firms governed by other stakeholders.

We hypothesised that employees' conservative capital structure choice stems from lower demand for debt as well as limited supply of debt. However, the results show that the capital structure choice in employee-governed firms is primarily determined by lower demand for debt. The findings that allow us to argue that conservative capital structure choice in employee-governed firms is primarily determined by demand side forces and only to a lesser extent by supply side forces are that employee-governed firms do not have to pledge more collateral when issuing debt and are not faced with higher cost of debt compared to the firms governed by other stakeholders. However, employee-governed firms avoid using debt because of their specific objective function and risk aversion. The results show that employee-governed firms are less levered at the same amount of earnings volatility than firms governed by other stakeholders, and that employee-governed firms, at least in some countries, to a larger extent rely on internal resources.

Empirically examining capital structure decisions in employee-governed firms, we provide strong empirical evidence of the capital structure implications under the assumption of an alternative corporate governance paradigm and contribute to the scarce literature available in this field. The main limitation of the empirical study relates to the inability of the proxy used to approximate employees' entrenchment, which nonetheless proved that it can explain conservative financial behaviour, to better explain a time-invariant permanent component that is a primary determinant of a firm's leverage and thus the larger portion of the variation in leverage. Other limitations refer to the abilities to draw strong conclusions about the effects of employees' ownership rights as well as ownership concentration, which results from using a database that is not the most appropriate for analysing ownership structures.

\section{REFERENCES}

Bhattacharya, S. (1979): Imperfect Information, Dividend Policy, and "the Bird in the Hand" Fallacy. The Bell Journal of Economics, 10(1): 259-270.

Berk, J.B. - Stanton, R.H. - Zechner, J. (2007): Human Capital, Bankruptcy and Capital Structure. Journal of Finance, 65(3): 891-926.

Bernheim, B.D. - Wantz, A. (1995): A Tax-Based Test of the Dividend Signalling Hypothesis. American Economic Review, 85(3): 532-551. 
Besanko, D. - Thakor, A.V. (1987): Collateral and Rationing: Sorting Equilibria in Monopolistic and Credit Markets. International Economic Review, 28(3): 671-689.

Bester, H. (1985): Screening vs. Rationing in Credit Markets with Imperfect Information. American Economic Review, 75(4): 850-855.

Bester, H. (1987): The Role of Collateral in Credit Markets with Imperfect Information. European Economic Review, 31(4): 887-899.

Chan, Y. - Kanatas, G. (1985): Asymmetric Valuations and the Role of Collateral in Loan Agreement. Journal of Money, Credit and Banking, 17(1): 84-95.

Chang, C. (1992): Capital Structure as an Optimal Contract between Employees and Investors. Journal of Finance, 47(3): 1141-1158.

Chemmanur, T.J. - Cheng, Y. - Zhang, T. (2013): Capital Structure and Employee Pay: An Empirical Analysis. Journal of Financial Economics, 110(2): 478-502.

Črnigoj, M. - Mramor, D. (2009): Determinants of Capital Structure in Emerging European Economies: Evidence from Slovenian Firms. Emerging Markets Finance \& Trade, 45(1): 72-89.

DeAngelo, H. - Masulis, R.W. (1980): Optimal Capital Structure under Corporate and Personal Taxation. Journal of Financial Economics, 8(1): 3-29.

Diamond, D.W. (1989): Reputation Acquisition in Debt Markets. Journal of Political Economy, 97(4): 828-862.

Diamond, D.W. (1991): Debt Maturity Structure and Liquidity Risk. The Quarterly Journal of Economics, 106(3): 709-737.

Faleye, O. - Mehrotra, V. - Morck, R. (2006): When Labour Has a Voice in Corporate Governance. Journal of Financial and Quantitative Analysis, 41(3): 489-510.

Flannery, M.J. (1986): Asymmetric Information and Risky Debt Maturity Choice. Journal of Finance, 41(1): 19-37.

Gintis, H. (1989): Financial Markets and the Political Structure of the Enterprise. Journal of Economic Behavior and Organization, 11(3): 311-322.

Harris, M. - Raviv, A. (1988): Corporate Control Contests and Capital Structure. Journal of Financial Economics, 20(1-2): 55-86.

Hart, O. - Moore, J. (1994): A Theory of Debt Based on the Inalienability of Human Capital. The Quarterly Journal of Economics, 109(4): 841-879.

Hernádi, P. - Ormos, M. (2012a): Capital Structure and Its Choice in Central and Eastern Europe. Acta Oeconomica, 62 (2): 229-263.

Hernádi, P. - Ormos, M. (2012b): What Managers Think of Capital Structure and How They Act: Evidence From Central and Eastern Europe. Baltic Journal of Economics, 12(2): 47-71.

Israel, R. (1991): Capital Structure and the Market for Corporate Control: The Defensive Role of Debt Financing. Journal of Finance, 46(4): 1391-1409.

Jaffee, D.M. - Russell, T. (1976):. Imperfect Information, Uncertainty, and Credit Rationing. Quarterly Journal of Economics, 90(4): 651-666.

Jensen, M.C. (1986): Agency Costs of Free Cash Flow, Corporate Finance, and Takeovers. American Economic Review, 76(2): 323-329.

Jensen, M.C. - Meckling, W.H. (1976): Theory of the Firm: Managerial Behavior, Agency Costs and Ownership Structure. Journal of Financial Economics, 3(4): 305-360.

John, K. - Williams, J. (1985): Dividends, Dilution, and Taxes: A Signaling Equilibrium. Journal of Finance, 40(4): 1053-1070.

Keeton, W.R. (1979): Equilibrium Credit Rationing. New York: Garland.

La Porta, R. - Lopez-De-Silanes, F. - Shleifer, A. - Vishny, R.W. (1997): Legal Determinants of External Finance. Journal of Finance, 52(3): 1131-1150. 
La Porta, R. - Lopez-De-Silanes, F. - Shleifer, A. - Vishny, R.W. (1998): Law and Finance. Journal of Political Economy, 106(6): 1113-1155.

Leland, H.E. - Pyle, D.H. (1977): Informational Asymmetries, Financial Structure, and Financial Intermediation. Journal of Finance, 32(2): 371-387.

Lemmon, M.L. - Zender, J.F. (2001): Looking under the Lamppost: An Empirical Examination of the Determinants of Capital Structure. Working Paper. University of Utah.

Lemmon, M.L. - Roberts, M.R. - Zender, J.F. (2008): Back to the Beginning: Persistence and the Cross-Section of Corporate Capital Structure. Journal of Finance, 63(4): 1575-1608.

Merton, R.C. (1974): On the Pricing of Corporate Debt: The Risk Structure of Interest Rates. Journal of Finance, 29(2): 449-470.

Miller, M.H. (1977): Debt and Taxes. Journal of Finance, 32(2): 261-275.

Miller, M.H. - Modigliani, F. (1961): Dividend Policy, Growth, and the Valuation of Shares. Journal of Business, 34(4): 411-433.

Miller, M.H. - Rock, K. (1985): Dividend Policy under Asymmetric Information. Journal of Finance, 40(4): 1031-1051.

Modigliani, F. - Miller, M.H. (1958): The Cost of Capital, Corporation Finance and the Theory of Investment. American Economic Review, 48(3): 261-297.

Modigliani, F. - Miller, M.H. (1963): Corporate Income Taxes and the Cost of Capital: A Correction. American Economic Review, 53(3): 433-443.

Morck, R. - Shleifer, A. - Vishny, R. (1988): Management Ownership and Market Valuation: An Empirical Analysis. Journal of Financial Economics, 20(1-2): 293-315.

Morellec, E. (2004): Can Managerial Discretion Explain Observed Leverage Ratios? The Review of Financial Studies, 17(1): 257-294.

Myers, S.C (1977): Determinants of Corporate Borrowing. Journal of Financial Economics, 5: $147-175$.

Myers, S.C. (1984): The Capital Structure Puzzle. Journal of Finance, 5(3): 575-592.

Myers, S.C. - Majluf, N.S. (1984): Corporate Financing and Investment Decisions When Firms Have Information that Investors Do Not Have. Journal of Financial Economics, 13(2): 187221.

Opler, T.C. - Titman, S. (1994): Financial Distress and Corporate Performance. Journal of Finance, 49(3): 1015-1040.

Pistor, K. - Raiser, M. - Gelfer, S. (2000): Law and Finance in Transition Economies. Economics of Transition, 8(2): 325-368.

Rajan, R. - Zingales, L. (1995): What do We Know about Optimal Capital Structure? Some Evidence from International Data. Journal of Finance, 50(5): 1421-1460.

Rajan, R. - Zingales, L. (1998): Power in a Theory of the Firm. Quarterly Journal of Economics, 113(2): 387-432.

Scott, J. (1977): Bankruptcy, Secured Debt, and Optimal Capital Structure. Journal of Finance, 32(1): $1-19$.

Stiglitz, J. - Weiss, A. (1981): Credit Rationing in Markets with Imperfect Information. American Economic Review, 71(3): 393-410.

Stiglitz, J. - Weiss, A. (1983): Incentive Effects of Terminations: Applications to the Credit and Labor Markets. American Economic Review, 73(5): 912-927.

Stulz, R. (1988): Managerial Control of Voting Rights: Financing Policies and the Market for Managerial Control. Journal of Financial Economics, 20(1-2): 25-54.

Titman, S. - Wessels, R. (1988): The Determinants of Capital Structure Choice. Journal of Finance, 43(1): 1-19.

Warner, J. (1977): Bankruptcy Costs: Some Evidence. Journal of Finance, 32(2): 337-347. 